\title{
スナバエネルギー回生機能を持つ単相昇圧形整流器
}

$\begin{array}{llll}\text { 正 員 根葉 } & \text { 保彦* } \text { 正 員 石坂 耕一* } \\ \text { 正 員 松本 } & \text { 洋和* } \text { 正 員 伊藤 良三* }\end{array}$

\section{Single-Phase Boost Rectifier with Snubber Energy Recovery Feature}

Yasuhiko Neba*, Member, Kouichi Ishizaka*, Member, Hirokazu Matsumoto*, Member, Ryozo Itoh*, Member

Single-phase boost rectifier with snubber energy recovery feature operating under the current-mode control with a turn-on at constant clock time is studied. In this rectifier, the resonant circuit consisting of small inductor and capacitor is added in DC circuit. The snubber energy is transferred to an additional resonant capacitor and can next be transferred to the load circuit when an insulated-gate bipolar transistor as the active power device is turned off. The experimental prototype is implemented to investigate the operation. The experimental results confirm that the proposed snubber energy recovery scheme has the feasibility.

キーワード : 単相整流器, 昇圧, スナバエネルギー回生, 共振回路, IGBT

Keywords: single-phase rectifier, step-up, snubber energy recovery, resonant circuit, IGBT

\section{1. まえがき}

単相ダイオードブリッジと昇圧形 DC-DC コンバータを 縦続接続した整流器 ${ }^{(1)}$ やその直流回路にポンプ動作用キャ パシタを付加した整流器 (2) は, スイッチモードで動作し, 可制御素子 1 個で実現できる。反面，可制御素子を保護す るために，一般にスナバ回路が使用され，スナバ損失の発 生は避けられない。本レターは，可制御素子のスナバエネ ルギーを有効利用するための共振回路を付加した単相昇圧 形整流器を提案したものであり，実験から，その有用性を 明らかにする。

\section{2. 回路構成と動作原理}

図 1 に本レターで提案する回路構成を示す。この整流器 は，単相ダイオードブリッジと昇圧形 DC-DC コンバータ を縦続接続した従来の整流器に小さなインダクタ $\mathrm{L}_{\mathrm{r}}$ とキャ パシタ $\mathrm{C}_{\mathrm{r}}$ からなる共振回路を付加したものであり， $\mathrm{C}_{\mathrm{s}}$ は スナバキャパシタである。本整流器の特長は, IGBT で示 すスイッチ $\mathrm{Q}$ のターンオン時に一旦キャパシタ $\mathrm{C}_{\mathrm{s}}$ から $\mathrm{C}_{\mathrm{r}}$ に移送蓄積されたスナバエネルギーが $\mathrm{Q}$ のターンオフ時に 負荷回路へ移送される点にある。ただし， $\mathrm{D}_{\mathrm{b} 1}$ は $\mathrm{C}_{\mathrm{s}}$ の短絡 放電， $\mathrm{D}_{\mathrm{b} 2}$ は電流 $\mathrm{i}_{\mathrm{r}}$ の逆流を阻止する。また， $\mathrm{D}_{\mathrm{r}}$ は $\mathrm{C}_{\mathrm{r}}$ が 逆極性に充電されるのを防ぐ役割を担う。以下，入力電流 $\mathrm{i}$ の制御法として電流追従制御を用いたときの $\mathrm{v}>0$ にお ける代表的な動作モードの概略を図 2 を参考にして説明す る。ただし, 可聴帯域外のクロックパルスによって生成さ

\footnotetext{
* 福岡大学

干 814-0180 福岡市城南区七隈 8-19-1

Fukuoka University

8-19-1, Nanakuma, Jonan-ku, Fukuoka 814-0180
}

れるオンゲート信号によって Q はターンオンし，i の絶対 值 $|\mathrm{i}|$ が電源電圧 $\mathrm{v}$ と同位相で可変振幅の正弦全波整流基準 波形 $\left|i^{*}\right|$ に達したとき，オンゲート信号は遮断されるもの とする。また，Qがターンオンするまで $\mathrm{i}$ は $\mathrm{D}_{\mathrm{r}}$ を通って負 荷回路へ流れ, $\mathrm{e}_{\mathrm{s}}=\mathrm{e}_{\mathrm{o}}, \mathrm{e}_{\mathrm{r}}=0$ かつ $\mathrm{i}_{\mathrm{r}}=0$ が成立している ものと仮定する。

（1）クロック周波数 $\mathrm{f}_{\mathrm{c}}$ から作成されたセットパルスに

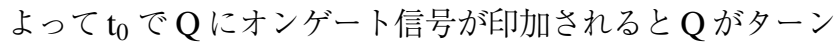
オンし, i は Q を通って流れる。また, $\mathrm{C}_{\mathrm{s}}$ は $\mathrm{C}_{\mathrm{s}}-\mathrm{D}_{\mathrm{b} 2}-\mathrm{L}_{\mathrm{r}}-\mathrm{C}_{\mathrm{r}}-\mathrm{Q}$ の共振回路で放電し， $\mathrm{i}_{\mathrm{r}}$ が正弦波状に増加しながら $\mathrm{C}_{\mathrm{r}}$ を 充電する。したがって, $\mathrm{Q}$ の電流は $\mathrm{i}+\mathrm{i}_{\mathrm{r}}$ に等しい。(2) $\mathrm{e}_{\mathrm{s}}=0$ になる $\mathrm{t}_{1}$ で $\mathrm{i}_{\mathrm{r}}$ は最大值に達し, $\mathrm{D}_{\mathrm{b} 1}$ がターンオン する。このとき, $\mathrm{Q}$ の電流は $\mathrm{i}$ のとなり， $\mathrm{i}_{\mathrm{r}}$ が減少しな がら $\mathrm{C}_{\mathrm{r}}$ を充電し続ける。( 3 ) $\mathrm{L}_{\mathrm{r}}$ が放電して $\mathrm{i}_{\mathrm{r}}=0$ になる $\mathrm{t}_{2}$ で $\mathrm{e}_{\mathrm{r}}$ は最大值に至り, $\mathrm{D}_{\mathrm{b} 1}$ がターンオフする。このこと

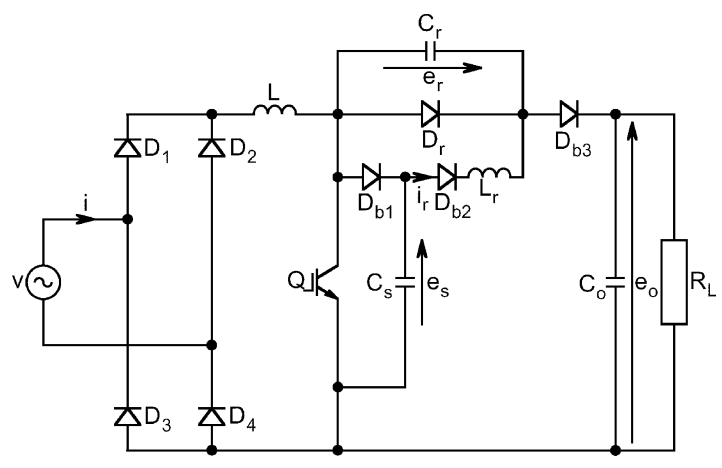

図 1 提案する単相昇圧形整流器

Fig. 1. Proposed single-phase boost rectifier. 


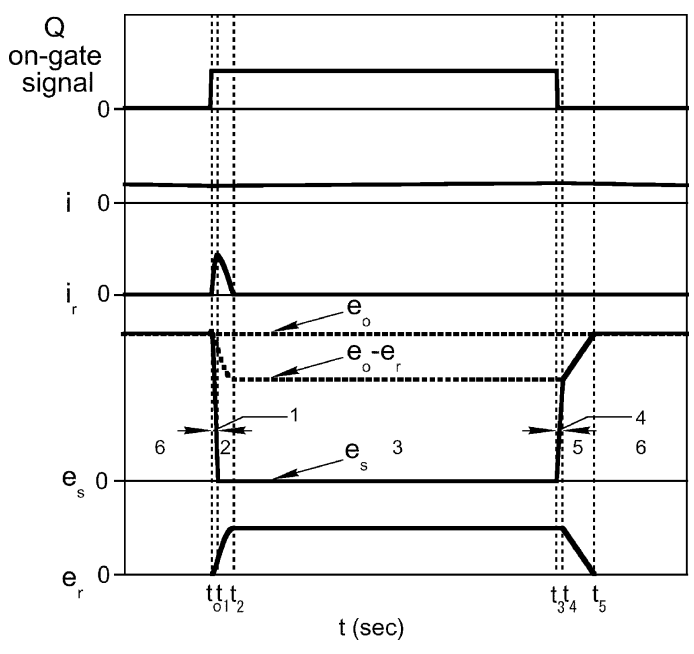

図 2 代表的な動作モード

Fig. 2. Typical modes of operation.

は， $\mathrm{C}_{\mathrm{s}}$ のエネルギーが $\mathrm{C}_{\mathrm{r}}$ に移送蓄積されたことを意味す る。他方，Qがターンオフされるまでこの状態が維持され る。(4) |i が|i*|に達した $\mathrm{t}_{3}$ で $\mathrm{Q}$ のオンゲート信号が遮断 され，これまで $\mathrm{e}_{\mathrm{s}}=0$ であったので $\mathrm{Q}$ はゼロ電圧スイッチ

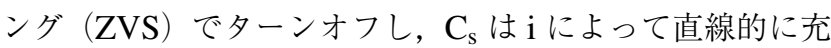
電される。( 5 ) $\mathrm{t}_{4}$ で $\mathrm{e}_{\mathrm{s}}=\mathrm{e}_{\mathrm{o}}-\mathrm{e}_{\mathrm{r}}$ なると $\mathrm{D}_{\mathrm{b} 3}$ がターンオン し, $\mathrm{i}$ は $\mathrm{C}_{\mathrm{s}}$ と $\mathrm{C}_{\mathrm{r}}$ を配置した枝に分流して $\mathrm{C}_{\mathrm{s}}$ が充電される と共に， $\mathrm{C}_{\mathrm{r}}$ が放電して $\mathrm{C}_{\mathrm{r}}$ に蓄積されていたエネルギーが 負荷回路へ移送される。（6） $\mathrm{e}_{\mathrm{r}}$ が減少して 0 になる $\mathrm{t}_{5}$ で $\mathrm{C}_{\mathrm{s}}$ が最大值 $\mathrm{e}_{\mathrm{o}}$ に達すると同時に $\mathrm{D}_{\mathrm{r}}$ が導通を開始して $\mathrm{i}$ は 電源から負荷回路へ流れる。この動作モードは Q がターン オンする前の状態に等しく, 次に $\mathrm{Q}$ がターンオンするまで 回路動作は変化しない。なお，モード (1)と (4)の継続時 間は非常に短く，スイッチング周期毎にスナバエネルギー が負荷回路へ供給される。ただし，vのゼロクロス近傍で は， $\mathrm{i}$ が小さく， $\mathrm{C}_{\mathrm{r}}$ が充電されたままの状態で $\mathrm{Q}$ がターン オンするために $\mathrm{C}_{\mathrm{s}}$ が放電しきれず， $\mathrm{Q}$ はハードスイッチ ングでターンオフする。

\section{3. 実験結果}

本レターでは, 動作条件および回路定数を電源電圧の実効 值 $\mathrm{V}=100[\mathrm{~V}](\mathrm{f}=60[\mathrm{~Hz}]), \mathrm{L}=1.99[\mathrm{mH}], \mathrm{C}_{\mathrm{s}}=0.1[\mu \mathrm{F}]$, $\mathrm{L}_{\mathrm{r}}=11.5[\mu \mathrm{H}], \mathrm{C}_{\mathrm{r}}=1.0[\mu \mathrm{F}], \mathrm{C}_{\mathrm{o}}=2200[\mu \mathrm{F}], \mathrm{f}_{\mathrm{c}}=20[\mathrm{kHz}]$, $\mathrm{R}_{\mathrm{L}}=32.56[\Omega]$ に設定して実験を行った。図 3 は, 出力電 圧 $\mathrm{e}_{\mathrm{o}}$ の平均值が $180[\mathrm{~V}]$ となるように $\mathrm{i}^{*}$ を調整したとき のディジタルオシロスコープによる実測波形である。眓よ り，入力電流 $\mathrm{i}$ は極性反転直後で $|\mathrm{i}|$ が $\left|\mathrm{i}^{*}\right|$ に追従できない ために歪みを生じるが(2)， $\mathrm{e}_{\mathrm{r}}$ が50[V]近くに達し，この電 圧で充電された $\mathrm{C}_{\mathrm{r}}$ のエネルギーが負荷回路へ移送されるの で，スナバエネルギーが有効に回生されていることが推察 できる。実験では, 変換器効率は 93.2[\%]であり, $0.1[\mu \mathrm{F}]$

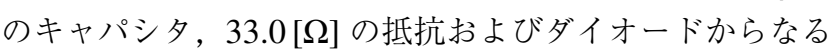

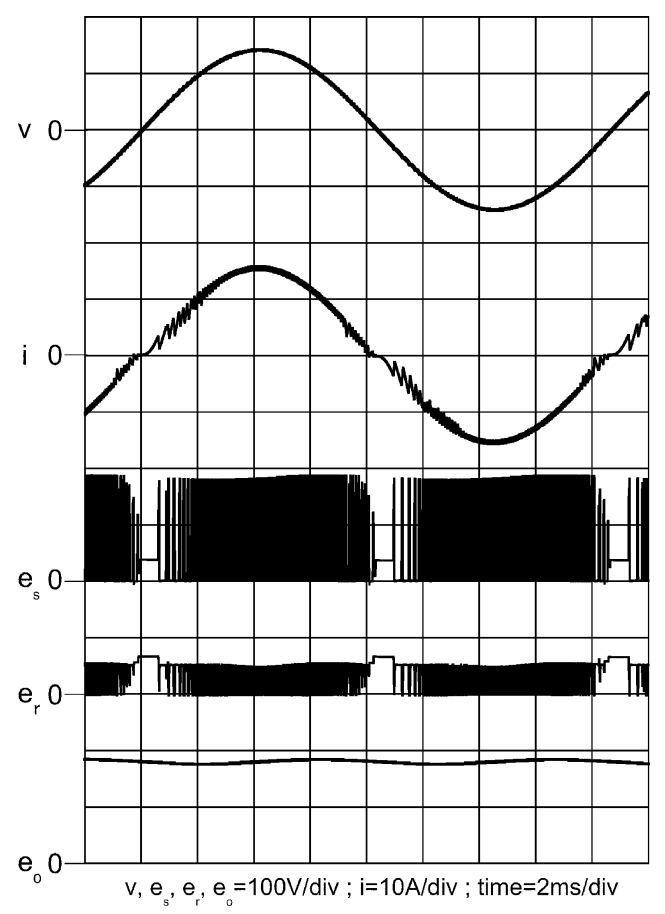

図 3 実測波形

Fig. 3. Measured waveforms.

従来のスナバを用いたときの変換器効率 $90.8[\%]$ に比べて $2.4 \%$ の効率改善が確認できた。なお, 図 3 の状態での入力 電流の総合歪み率 (THD) は 4.41 [\%], 総合力率は 0.998 であった。

\section{4. あとがき}

以上, 従来のスイッチモード単相整流器に共振回路を付 加した構成を提案し, 実験から, スナバエネルギー回生の 効果が確認できた。なお, 例えば, 電流不連続モードで動 作するスイッチモード整流器 ${ }^{(3)}$ は入力電流を正弦波化でき るが，これに本レターの共振回路を適用すれば，スナバエ ネルギーの有効利用だけでなく, 可制御素子のターンオン・ ターンオフ時ともソフトスイッチング動作が可能になるも のと考えられ, 今後検討する予定である。

(平成 21 年 3 月 10 日受付, 平成 21 年 3 月 30 日再受付)

$$
\text { 文献 }
$$

(1) I. Takahashi and W. Ikeshita: "Improvement of Input Current Waveform of a Single-Phase Rectifier Circuit", T. IEE Japan, Vol.105-B, No.2, p.82 (1985-2) (in Japanese)

高橋 勲 - 池下 亘:「単相整流回路の入力電流波形改善」, 電学論 B, 105, 2, p.82 (1985-2)

(2) H. Oishi, Y. Neba, K. Ishizaka, and R. Itoh: "Single-Phase Boost Rectifier Adding a Capacitor for Pumping Action in DC Circuit", T. IEE Japan, Vol.127-D, No.3, pp.347-348 (2007-3) (in Japanese)

大石隼人・根葉保彦・石坂耕一・伊藤良三：「直流回路にポンプ動 作用キャパシタを付加した単相昇圧形整流器」, 電学論 D, 127, 3, pp.347-348 (2007-3)

(3) A.R. Prasad, P.D. Ziogas, and S. Manias: "An Active Power Factor Correction Technique for Three-Phase Diode Rectifiers", IEEE Trans. Power Electron., Vol.6, No.1, pp.83-92 (1991-1) 